\title{
Aberration of FHIT Gene is Associated with Increased Tumor Proliferation and Decreased Apoptosis-Clinical Evidence in Lung and Head and Neck Carcinomas
}

\author{
Krešimir Pavelić,, Šimun Križanac, ${ }^{1}$ Tamara Čačev, ${ }^{1}$ Marijana Popović Hadžija, ${ }^{1}$ Senka Radošević, ${ }^{2}$ \\ Ivana Crnić, ${ }^{1}$ Sonja Levanat, ${ }^{1}$ and Sanja Kapitanović ${ }^{1}$ \\ ${ }^{1}$ Ruđer Bošković Institute, Division of Molecular Medicine, Zagreb, Croatia \\ ${ }^{2}$ PLIVA d.d., Research \& Development, Zagreb, Croatia \\ Accepted April 5, 2001
}

\begin{abstract}
Background: Human FHIT (fragile histidine triad) gene is highly conserved gene homologous to a group of genes identified in prokaryotes and eukaryotes. Loss of FHIT function may be important in the development and/or progression of various types of cancer.

Materials and Methods: We undertook a clinical study to analyze the relation between aberrant function of FHIT gene, tumor cell proliferation, and intensity of apoptosis as well as prognostic output in lung and squamous cell head and neck carcinoma (HNSCC). Status of FHIT gene, expression of $\mathrm{p} 21^{\mathrm{waf} 1}$, intensity of apoptosis, and cell proliferation were analyzed in HNSCC and lung carcinoma tissues by molecular genetic methods, immunohistochemistry, [ $\left.{ }^{3} \mathrm{H}\right]$-thymidine labeling method, and FACScan analysis in frozen and paraffin-embedded tissue sections.

Results: The majority of the malignant lung and HNSCC lesions displayed aberrant expression of FHIT gene, followed by low or negative expression of $\mathrm{p} 21^{\text {wafl }}$, and increased intensity of cell proliferation. Similar results were obtained on synchronous combinations of normal, precancerous, and
\end{abstract}

cancerous head and neck tissues. The observed changes increased with progression of these lesions. We examined tumor and corresponding normal tissue samples for microsatellite markers D3S1300 and D3S4103 to evaluate the loss of heterozygosity $(\mathrm{LOH})$ at the FHIT gene loci. We found high percentage of $\mathrm{LOH}$ in both lung tumors and HNSCC (75\% for D3S1300 and 79\% for D3S4103 in lung cancer, and $87 \%$ for D3S1300 and $78 \%$ for D3S4103 in HNSCC). The median survival time of the patients suffering from lung cancer without FHIT protein expression was 22.46 months and that of the patients with FHIT expression 36.04 months. FHIT-negative cases tended to correlate with a worse prognosis, but this was not statistically significant. Median survival time of HNSCC patients without FHIT protein expression was 30.86 months and that of the patients with FHIT expression was 64.04 months $(p<0.05)$.

Conclusions: Our results show a correlation between aberrant FHIT expression, a low rate of apoptosis, and high tumor cell proliferation. Aberrant FHIT gene could be a prognostic marker in lung cancer.

\section{Introduction}

Sozzi et al. (1) identified the human FHIT (fragile histidine triad) gene using an exon trapping strategy from cosmids covering specific region at $3 \mathrm{p} 14.2$ involved in epithelial cancer cell lines $(1,2)$. FHIT is a highly conserved gene homologous to a group of genes identified in prokaryotic and eukaryotic organisms. Occurrence of abnormal transcripts of the FHIT gene has been reported in various types of cancer (1-5). On the other hand, aberrant transcripts are sometimes found in nonneoplastic tissues. This suggests that the presence of abnormal FHIT transcripts, in terms of their frequency and variety, is not cancer-specific in lung carcinogenesis, and the abnormality may be

Address correspondence and reprint requests to: Krešimir Pavelić, MD, PhD, Ruđer Bošković Institute, Division of Molecular Medicine, Bijenička 54, P.O. Box 180, HR-10002 Zagreb, Croatia. Phone: 385 l 456 1010; Fax 3851456 1010; e-mail: pavelic@rudjer.irb.hr due to abnormal splicing and processing of the transcripts (6).

The FHIT gene contains the most common fragile site of the human genome FRA3B (3); it encompassing the FRA3B fragile region and encodes a protein of Mr 16,800 with diadenosine triphosphate hydrolase activity dependent on the conserved histidine triad encoded by exon 8 (7). The multiple genetic lesions within FHIT gene may be explained by the location of the gene within a fragile site, by definition highly susceptible to breakage induced by carcinogens (8).

In some tumors, particularly those associated with environmental carcinogens, alterations in the FHIT gene occur quite early in the development of cancer. In other cancers, FHIT inactivation seems to be a later event, possibly associated with progression to more aggressive neoplasias (9).

Loss of heterozygosity $(\mathrm{LOH})$ at $3 \mathrm{pl} 4$ has been observed frequently in squamous cell carcinomas of the head and neck (HNSCC) and lung cancers (10-13). Small cell lung tumors $(80 \%)$ and non-small 
cell lung cancers (40\%) showed abnormalities in RNA transcripts of $F H I T$, and $76 \%$ of the tumors exhibited loss of FHIT alleles. Abnormal lung tumor transcripts lack two or more exons of the FHIT gene. These data suggest a critical (or at least important) role for the FHIT gene in lung carcinogenesis (4).

Given the concordance between the occurrence of $\mathrm{LOH}$ affecting microsatellite markers within the FHIT gene and abnormal FHIT transcript in tobaccorelated cancers such as lung (1) and head and neck tumors $(4,12)$, loss of one FHIT allele is likely to be a crucial step leading to loss of function of the gene. Sozzi et al. (14) showed that LOH affected at least one locus of the FHIT gene (observed in $80 \%$ tumors in the smokers but in only $22 \%$ tumors of nonsmokers). These data indicate that FRA3B is a preferential target of tobacco smoke damage at a molecular level. Nonsmoker patients with FHIT abnormalities revealed a significant exposure to passive smoke, either at home or at work.

Siprashvili et al. (15) observed a suppression of tumorigenicity in cancer-derived cell lines, including tumor cell lines derived from gastric carcinomas, after restoring FHIT protein expression. FHIT gene transfer into lung cancer cell line H460 lacking FHIT protein expression resulted in revision of tumorigenicity, significant inhibition of cell growth, and a high rate of apoptosis-induced DNA strand breaks in stable clones. An increased level of p2 $1^{\text {wafl }}$ protein paralleled by an up-regulation of p2 $1^{\text {wafl }}$ transcripts was also found in FHIT-expressing clones compared with the H460 cell line (16). When delivered at high efficiency by a recombinant adenoviral vector, FHIT gene functions as a tumor suppressor gene both in vitro and in vivo. Over-expression of the FHIT gene significantly inhibits cell growth in various adenoviral vector FHIT-transduced human lung cancer cells and head and neck carcinoma cells with FHIT gene abnormalities, but not in normal human bronchial epithelial cells. Over-expression of FHIT gene induces cell apoptosis and alters cellcycle processes. The cells accumulate FHIT protein in S-phase after transduction (17). FHIT-deficient mice develop a Muir-Torre-like syndrome (18). It is unclear whether this observation has any clinical relevance.

Here we undertook a clinical study to prove experimental data regarding the correlation between aberrant function of FHIT gene, tumor cell proliferation, intensity of programmed cell death (apoptosis), and prognostic output in lung and head and neck cancer.

\section{Materials and Methods}

\section{Tumor Specimens}

HNscC. Tumor and adjacent normal specimens from patients with primary HNSCC were from Croatian Human Tumor Bank (19). Material from 74 patients suffered from HNSCC (58 men aged 42-75 years and 16 women aged 50-73 years) was studied. Twentythree samples were used for comparative study (FHIT gene status, p2 $1^{\text {wafl }}$, apoptosis, and $\left[{ }^{3} \mathrm{H}\right]$-thymidine $\left\{{ }^{3} \mathrm{H}\right]$-thy $\}$ labeling). Twenty-three different samples were used for loss of $\mathrm{LOH}$ analysis; in 27 samples, p2 $1^{\text {wafl }}$ expression and apoptosis were compared with FHIT gene status. Samples were snap frozen in various stages and analyzed. None of patients included in this study had undergone any preoperative treatment.

There were also 12 patients with synchronous lesions: dysplasia, carcinoma in situ, and cancer of the head and neck (Table 1). Their samples were analyzed for FHIT gene status, p2 $1^{\text {waf } 1}$ expression, and apoptosis; the same fresh carcinoma samples were used in tumor kinetic assay immediately after surgery.

FHIT protein was analyzed immunohistochemically in 120 archival, paraffin-embedded samples (80 men aged $42-81$ years and 40 women aged 57-79 years); 82 patients from this group were used for survival analysis.

LUNG CANCERs. A total of 48 lung carcinomas (20 squamous cell carcinomas, 10 adenocarcinomas, 12 large cell carcinomas, and 6 adenosquamous carcinomas) obtained from Croatian Human Tumor Bank were analyzed. These were obtained from patients treated surgically ( 32 men, aged 35-70 years, mean 60 years; and 16 women, aged 48-70, mean 59 years). Twenty tissue samples were used for comparative study (Table 2) and 28 informative samples were used for LOH analysis (Table 3). Eighty-two patients suffering from lung cancer were used for survival analysis.

\section{Tissue Handling}

All specimens were obtained during routine surgery. The tissues were snap frozen in liquid nitrogen shortly after surgical removal and stored at $-80^{\circ} \mathrm{C}$. A part of each frozen tumor sample was also embedded in paraffin. Sections of each paraffin block were stained with hematoxylin and eosin to confirm the exact tissue analyzed and to determine the proportion of tumor cells in the sample (it had to be more than $80 \%$ in tumor samples). Frozen sections adjacent to those used for histopathologic analysis were used for RNA, immunohistochemical, and FACS analysis. For $\left[{ }^{3} \mathrm{H}\right]-$ Thy labeling, fresh resected samples were collected into sterile vessels containing RPMI 1640 medium with $10 \%$ heat-inactivated fetal calf serum and brought to the laboratory immediately. All persons gave their informed consent prior to their inclusion, and the local ethics committees approved the study.

\section{Immunohistochemistry}

IMMUNOHISTOCHEMICAL DETECTION OF P21 PROTEIN. Immunohistochemical analysis was done on frozen sections. The method described by Pavelić et al. 
Table 1. FHIT gene status, p21 expression, and $\left[{ }^{3} \mathrm{H}\right]-$ thymidie labeling in patients with synchronous displasia, CIS, and HNSCC.

\begin{tabular}{|c|c|c|c|c|c|c|c|c|c|c|c|c|}
\hline \multirow{2}{*}{$\begin{array}{l}\text { Patient } \\
\text { No. }\end{array}$} & \multicolumn{3}{|c|}{$\begin{array}{c}\text { Normal Adjacent } \\
\text { to Lesion }\end{array}$} & \multicolumn{3}{|c|}{ Dysplasia } & \multicolumn{3}{|c|}{ CIS } & \multicolumn{3}{|c|}{ Cancer } \\
\hline & FHIT & p21 & ${ }^{3} \mathrm{H}-[\mathrm{Thy}]$ & FHIT & p21 & ${ }^{3} \mathbf{H}-[$ Thy $]$ & FHIT & p21 & ${ }^{3} \mathrm{H}-[\mathrm{Thy}]$ & FHIT & p21 & ${ }^{3} \mathrm{H}-[\mathrm{Thy}]$ \\
\hline 1 & $\mathrm{~N}$ & 3 & 1.7 & $\mathrm{~N}$ & 1 & 2.3 & $\mathrm{~N}$ & 3 & 1.9 & At + Em (8) & 1 & 9.7 \\
\hline 2 & $\mathbf{N}$ & 3 & 2.7 & At + Em (4-8) & 0 & 4.3 & At + Em (4-8) & 0 & 5.4 & At + Em (4-8) & 0 & 5.5 \\
\hline 3 & $A t+\operatorname{Em}(4-8)$ & 0 & 2.0 & $A t+\operatorname{Em}(4-8)$ & 0 & 3.8 & $A t+\operatorname{Em}(4-8)$ & 0 & 2.1 & At + Em (4-8) & 1 & 4.5 \\
\hline 4 & At + Em (8) & 1 & 5.9 & At + Em (8) & 1 & 4.2 & At + Em (8) & 0 & 3.3 & At + Em (8) & 0 & 3.8 \\
\hline 5 & $\mathbf{N}$ & 2 & 0.8 & $\mathrm{~N}$ & 2 & 1.5 & $\mathrm{~N}$ & 1 & 4.0 & $\mathrm{~N}$ & 0 & 4.9 \\
\hline 6 & $\mathrm{~N}$ & 2 & 1.9 & $\mathrm{~N}$ & 2 & ND & $\mathbf{N}$ & ND & 4.0 & $\mathrm{~N}$ & 0 & 3.9 \\
\hline 7 & At $+\operatorname{Em}(5-7)$ & 1 & 4.4 & At + Em (5-7) & 0 & 3.0 & At $+\operatorname{Em}(5-7)$ & 1 & 7.9 & At + Em (5-7) & 0 & 10.1 \\
\hline 8 & $\mathbf{N}$ & ND & ND & $\mathrm{N}$ & ND & ND & At + Em (4-8) & ND & 12.7 & At + Em (4-8) & 0 & 14.1 \\
\hline 9 & $\mathrm{~N}$ & 3 & 2.9 & $\mathrm{~N}$ & 2 & ND & $\mathrm{N}$ & 1 & 3.4 & At + Em (4-8) & 1 & ND \\
\hline 10 & $\mathrm{~N}$ & 3 & ND & $\mathrm{N}$ & 2 & 7.6 & At + Em (8) & 0 & 7.0 & $A t+E m(8)$ & 0 & 10.8 \\
\hline 11 & $\mathrm{~N}$ & 2 & ND & At + Em (8) & 0 & ND & At + Em (8) & 1 & ND & At + Em (8) & 1 & ND \\
\hline 12 & $\mathrm{~N}$ & 3 & 1.0 & $\mathrm{~N}$ & 3 & 1.9 & $\mathbf{N}$ & ND & 4.1 & $\mathrm{~N}$ & 2 & 7.1 \\
\hline
\end{tabular}

$\mathrm{N}$, normal; ND, not determined; At, aberrant transcript; Em, exon missing (number of exon); $\left[{ }^{3} \mathrm{H}\right]-\mathrm{Thy},\left[{ }^{3} \mathrm{H}\right]$-thymidie labeling $\times 10^{3}$; CIS, carcinoma in situ; HNSCC, squamous cell carcinoma of the head and neck.

Table 2. FHIT gene status, smoking status, tumor stage, p21 expression, $\left[{ }^{3} \mathrm{H}\right]$-thymidie labeling, and apoptosis in lung cancer.

\begin{tabular}{|c|c|c|c|c|c|c|c|}
\hline Case No. & Lung Cancer Type & S/A Status & Stage & FHIT Status & p21 & {$\left[{ }^{3} \mathbf{H}\right]-$ Thy } & Apoptosis (\%) \\
\hline 1 & Adenocarcinoma & $S$ & $\mathrm{~T}_{2} \mathrm{~N}_{0} \mathrm{M}_{0}$ & $A t+\operatorname{Em}(8)$ & 0 & 4.5 & 47 \\
\hline 2 & Adenocarcinoma & $S$ & - & $A t+\operatorname{Em}(8)$ & 0 & 3.9 & 22 \\
\hline 3 & Adenocarcinoma & $S$ & $\mathrm{~T}_{2} \mathrm{~N}_{2} \mathrm{M}_{0}$ & NAt + Em (4-8) & 0 & 17.1 & 11 \\
\hline 4 & Adenocarcinoma & $S$ & $\mathrm{~T}_{3} \mathrm{~N}_{2} \mathrm{M}_{2}$ & $\mathrm{NAt}+\operatorname{Em}(5-7)$ & 1 & 10.0 & 15 \\
\hline 5 & Adenocarcinoma & $S$ & $\mathrm{~T}_{2} \mathrm{~N}_{0} \mathrm{M}_{0}$ & $\mathbf{N}$ & 3 & 2.0 & 59 \\
\hline 6 & Squamous cell & $S$ & $\mathrm{~T}_{4} \mathrm{~N}_{3} \mathrm{M}_{1}$ & $\mathbf{N}$ & 3 & 1.7 & 67 \\
\hline 7 & Squamous cell & NK & $\mathrm{T}_{3} \mathrm{~N}_{2} \mathrm{M}_{1}$ & $\mathrm{NAt}+\mathrm{Em}(8)$ & 1 & 5.7 & 22 \\
\hline 8 & Squamous cell & $S$ & $\mathrm{~T}_{3} \mathrm{~N}_{2} \mathrm{M}_{1}$ & $\mathrm{NAt}+\operatorname{Em}(5-7)$ & 2 & 7.3 & 22 \\
\hline 9 & Squamous cell & S & $\mathrm{T}_{4} \mathrm{~N}_{3} \mathrm{M}_{1}$ & $\mathrm{NAt}+\mathrm{Em}(8)$ & 0 & 9.4 & 18 \\
\hline 10 & Squamous cell & $S$ & $\mathrm{~T}_{3} \mathrm{~N}_{2} \mathrm{M}_{0}$ & $\mathrm{NAt}+\mathrm{Em}(8)$ & 0 & 9.7 & 5 \\
\hline 11 & Squamous cell & $S$ & $\mathrm{~T}_{2} \mathrm{~N}_{2} \mathrm{M}_{0}$ & $\mathrm{NAt}+\mathrm{Em}(8)$ & 1 & 4.9 & 14 \\
\hline 12 & Squamous cell & $S$ & $\mathrm{~T}_{2} \mathrm{~N}_{0} \mathrm{M}_{0}$ & At + Em (4-7) & 0 & 7.3 & 29 \\
\hline 13 & Squamous cell & $S$ & $\mathrm{~T}_{2} \mathrm{~N}_{0} \mathrm{M}_{\mathrm{O}}$ & At $+\operatorname{Em}(4-7)$ & 1 & 9.9 & 12 \\
\hline 14 & Squamous cell & $S$ & $\mathrm{~T}_{3} \mathrm{~N}_{3} \mathrm{M}_{1}$ & $A t+\operatorname{Em}(4-7)$ & 1 & 4.6 & 17 \\
\hline 15 & Squamous cell & $S$ & $\mathrm{~T}_{2} \mathrm{~N}_{0} \mathrm{M}_{0}$ & $\mathrm{NAt}+\mathrm{Em}(8)$ & 0 & 9.0 & 21 \\
\hline 16 & Squamous cell & $S$ & $\mathrm{~T}_{3} \mathrm{~N}_{2} \mathrm{M}_{1}$ & $\mathrm{NAt}+\mathrm{Em}(8)$ & 0 & 7.6 & 20 \\
\hline 17 & Large cell & $S$ & $\mathrm{~T}_{3} \mathrm{~N}_{2} \mathrm{M}_{0}$ & $A t+\operatorname{Em}(5-7)$ & 1 & 5.5 & 15 \\
\hline 18 & Large cell & NK & - & $\mathrm{NAt}+\mathrm{Em}(4-8)$ & 1 & 7.3 & ND \\
\hline 19 & Large cell & $S$ & $\mathrm{~T}_{2} \mathrm{~N}_{0} \mathrm{M}_{0}$ & $\mathrm{NAt}+\mathrm{Em}(4-8)$ & 0 & 7.8 & ND \\
\hline 20 & Large cell & S & $\mathrm{T}_{3} \mathrm{~N}_{3} \mathrm{M}_{1}$ & $\mathrm{NAt}+\mathrm{Em}(4-8)$ & 0 & 3.9 & 27 \\
\hline
\end{tabular}

N, normal; ND, not determined; At, aberrant transcript; Em, exon missing (number of exon); $\left[{ }^{3} \mathrm{H}\right]-\mathrm{Thy},\left[{ }^{3} \mathrm{H}\right]-\mathrm{thymidie}$ labeling $\left(\times 10^{3}\right)$; S; smoking history; NK, not known. 
Table 3. LOH of FHIT allele in lung tumors and HNSCC.

\begin{tabular}{lccc}
\hline Cancer Type & No. of Cases & LOH at D3S1300 & LOH at D3S4103 \\
\hline Lung adenocarcinoma & 5 & $5 / 5$ & $4 / 5$ \\
Lung squamous cell & 10 & $10 / 10$ & $10 / 10$ \\
Lung adenosquamous & 6 & $2 / 6$ & $3 / 6$ \\
Lung large cell & 7 & $4 / 7$ & $5 / 7$ \\
Total & 28 & $21 / 28$ & $22 / 28$ \\
HNSCC-tongue & 10 & $9 / 10$ & $9 / 10$ \\
HNSCC-tonsil & 7 & $7 / 7$ & $6 / 7$ \\
HNSCC-alveolar ridge & 4 & $2 / 4$ & $2 / 4$ \\
HNSCC-retromolar & 2 & $2 / 2$ & $1 / 2$ \\
Total & 23 & $20 / 23$ & $18 / 23$ \\
\end{tabular}

(20) was used. Briefly, the tissue sections were fixed and the endogenous peroxidase activity was quenched by 15-min incubation in methanol containing $3 \%$ hydrogen peroxide (Sigma, Taufkirchen, Germany). Nonspecific binding was blocked by applying normal rabbit serum in a humidity chamber at a dilution of $1: 10$ for $30 \mathrm{~min}$. Primary mouse mAb to p2 $1^{\text {Waf } 1}$ (Oncogene Science, Cambridge, MA) at a concentration of $5 \mu \mathrm{g} / \mathrm{ml}$ were applied overnight at $4^{\circ} \mathrm{C}$. The secondary antibody (rabbit to mouse immunoglobulins; DAKO, Glostrup, Denmark) was applied for $\mathrm{l} \mathrm{hr}$ at room temperature. Peroxidase-antiperoxidase (PAP, DAKO, Glostrup, Denmark) conjugate diluted 1:100 in phosphate-buffered saline (PBS) was applied for $45 \mathrm{~min}$ at room temperature. The slides were stained with diaminobenzidine tetrahydrochloride (DAB, Sigma) and then counterstained with hematoxylin. Finally, the slides were mounted in Canada balsam. Specificity controls comprised preabsorbtion of monoclonal antibodies with their appropriate antigen/peptides as recommended by the manufacturer. Antibodies were titrated to the lowest dilution having acceptable background staining.

The localization and level of specific immunostaining for each slide was evaluated in the whole tumor area. The relative level of specific immunostaining and its localization were judged. The relative intensity of cell immunostaining was evaluated, semiquantitatively, so that no staining was denoted (0), weak staining was denoted (1), moderate (2), and strong (3).

IMMUNOHISTOCHEMICAL DETECTION OF FHIT PROTEIN. Immunohistochemical analysis was done retrospectively. Resected tumors were fixed in a $10 \%$ formaldehyde solution and embedded in paraffin. Four-micrometer sections were cut and mounted on slides.
Staining was performed using the avidin-biotin method. Anti-FHIT polyclonal antibody (F-130, 1:180 dilution; IBL, Gumma, Japan) was used for FHIT detection. Sections were incubated 12 for hr at $4^{\circ} \mathrm{C}$ with antibody in PBS containing $5 \%$ goat serum and were counterstained with hematoxylin. To evaluate the specificity of the antibody, the absorption test was done using FHIT antigen peptide according to manufacturer's instruction. For the negative control, the primary antibody was replaced with normal rabbit serum. As positive control we used tumor tissue with the wild-type of FHIT gene (HPSCC, case \# 7, Table 1).

The intensity of staining was evaluated in four areas of the slide section for correlation and confirmation of the tissue analysis. Criteria for the analysis were as follows: no staining or very weak staining was classified as negative staining, heterogenous staining and weak staining was classified as reduced staining, and strong staining was classified as positive staining (21).

\section{DNA LOH Analysis}

All specimens were examined by routine hematoxylin-eosin staining to determine the proportion of tumor cells in the sample (it had to be more than $80 \%$ ). Control normal DNA was extracted from corresponding histologically normal tissue of the patients. DNA extraction was performed using proteinase $\mathrm{K}$ digestion and phenol chloroform extraction. To analyze $\mathrm{LOH}$ at the FHIT gene, we used D3S1300 dinucleotide repeat and D3S4103 trinucleotide repeat. Genomic DNA (200 ng) was used as a template in a reaction volume of $25 \mu$ l containing 5 pmol of each specific primer $(21,22), 50 \mu \mathrm{M}$ of each dNTP, and 1 U Taq DNA polymerase (BioSystems, Warrington, United Kingdom). Polymerase chain reactions (PCR) were carried out in a BioSystems Ther- 
mocycler 2400 for 30 cycles. Annealing temperatures for each set of primers were optimized in pilot studies before processing experimental samples.

For microsatellite analysis $5 \mu \mathrm{l}$ of PCR product were mixed with $3 \mu \mathrm{l}$ of loading buffer and loaded onto $1-\mathrm{mm}$ thick, $35 \times 30 \mathrm{~cm}, 10 \%$ nondenaturing polyacrylamide gel. Electrophoresis was performed in $1 \times$ Tris/borate/EDTA buffer for $18 \mathrm{hr}$ at $400 \mathrm{~V}$, at room temperature. The gels were silver stained.

LOH was defined by visible change in allele: allele ratio in tumors compared with matching normal tissue. Allelic deletion of FHIT was judged by a positive $\mathrm{LOH}$ at any of the two sites.

\section{RNA Extractïion and Reverse Transcription PCR}

For total RNA extraction, tumor tissue samples were homogenized in $1 \mathrm{ml}$ of a solution containing $4 \mathrm{mM}$ guanidinium thiocyanate, $25 \mathrm{mM}$ sodium citrate, $\mathrm{pH}$ 7.0, $5 \mathrm{~g} / \mathrm{l}$ sarcosyl, and $0.1 \mathrm{M} / \mathrm{l}$ 2-mercaptoethanol. The subsequent procedure was the same as described previously (23).

For reverse transcription $\left(42^{\circ} \mathrm{C}\right.$ for $\left.1 \mathrm{hr}\right), 5 \mu \mathrm{g}$ denatured RNA $\left(10 \mathrm{~min}, 70^{\circ} \mathrm{C}\right), 2 \mu \mathrm{l} 10 \times$ reverse transcriptase buffer $(500 \mathrm{mM}$ Tris $\mathrm{HCl}, \mathrm{pH} 8.3,300 \mathrm{mM}$ $\mathrm{KCl}, 80 \mathrm{mM} \mathrm{MgCl}, 100 \mathrm{mM}$ dithiothreitol; New England BioLabs Inc.), $200 \mu \mathrm{M}$ each dNTPs, $25 \mathrm{U}$ Moloney Murine Leukemia Virus reverse transcriptase (New England BioLabs Inc., Frankfurt am Main, Germany), and $0.4 \mathrm{mM}$ oligo (dT) 18 were used in a total volume of $20 \mu \mathrm{l}$. The cDNA was heat denatured $\left(95^{\circ} \mathrm{C}, 5 \mathrm{~min}\right)$ before PCR and then amplified in separate tubes with primers for the human $\beta$-actin gene and/or with primers for FHIT gene.

\section{FHIT Expression Analysis}

Half of microliter of cDNA was used for PCR amplifications with primers 5U2 and 3D2 from FHIT exons 1 and 10, respectively (3). Amplification was carried out in $25 \mu \mathrm{l}$ volume. The PCR mixture consisted of $0.5 \mu \mathrm{l}$ of cDNA, $2.5 \mu \mathrm{l}$ of $10 \times$ PCR buffer II (Bio Systems), $1.5 \mathrm{mM}$ of $\mathrm{MgCl}_{2}, 50 \mu \mathrm{M}$ of each dNTP, 5 pmol of each specific primer, and I U of Taq DNA polymerase (Bio Systems, Warrington, United Kingdom). The PCR consisted of an initial denaturation step at $95^{\circ} \mathrm{C}$ for $5 \mathrm{~min}$, followed by 45 cycles of 30 sec at $96^{\circ} \mathrm{C}, 30 \mathrm{sec}$ at $56^{\circ} \mathrm{C}$, and $45 \mathrm{sec}$ at $72^{\circ} \mathrm{C}$. Final extension lasted $10 \mathrm{~min}$. The PCR products were resolved by agarose gel electrophoresis $(1.5 \%$ agarose stained with $0.5 \mu \mathrm{g} / \mathrm{ml}$ ethidium bromide).

\section{Proliferation Assay}

Tumor cell kinetics were evaluated by the thymidinelabeling index (24). Tumor fragments were incubated immediately after surgery for $1 \mathrm{hr}$ at $37^{\circ} \mathrm{C}$ with shaking in 1640 RPMI medium with $15 \%$ of fetal calf serum and $5 \%$ of normal human serum, $1 \%$ L-glutamine, $100 \mathrm{mg} / \mathrm{ml}$ of streptomycin, $100 \mathrm{U} /$ $\mathrm{ml}$ of penicillin, and $6 \mathrm{mCi} / \mathrm{ml}$ of $\left[{ }^{3} \mathrm{H}\right]$-thy $(5 \mathrm{Ci} /$ mmol; Amersham Pharmacia, Zagreb, Croatia). Tumor cell kinetic was expressed as the count per minute (cpm) of labeled cells among the total number of tumor cells. A minimum of 2000 cells was scored for each sample.

\section{Analysis of Apoptosis}

DNA LADDER. DNA fragments were isolated according to the method described by Herrmann et al. (25). Tumor tissue was disaggregated, pelleted by centrifugation, and washed two times in PBS. Afterward, the cells were resuspended for $10 \mathrm{sec}$ in $100 \mu \mathrm{l}$ of lysis buffer ( $1 \% \mathrm{NP}-40$ in $20 \mathrm{nM}$ of EDTA, $50 \mathrm{mM}$ of Tris- $\mathrm{HCl}, \mathrm{pH} 7.5$ ) and centrifuged for $5 \mathrm{~min}$ at $3000 \mathrm{~g}$. The supernatant was transferred to a new Eppendorf tube while the pellet was incubated once more with $100 \mu \mathrm{l}$ of lysis buffer and centrifuged as before. The supernatants were pooled together and incubated for $2 \mathrm{hr}$ in $1 \%$ SDS and RNAse $(5 \mu \mathrm{g} / \mu \mathrm{l})$ at $56^{\circ} \mathrm{C}$ after which the proteinase $\mathrm{K}$ was added in final concentration $2.5 \mathrm{mg} / \mathrm{ml}$ overnight. DNA fragments were pelleted by addition of $1 / 2$ volume of $10 \mathrm{M}$ ammonium acetate and 2.5 volume of prechilled absolute ethanol. After centrifugation (30 min, 12,000 g), the pellet was washed with $70 \%$ ethanol, centrifuged for $10 \mathrm{~min}$ at $12,000 \mathrm{~g}$, dried, dissolved in $20 \mu \mathrm{l}$ of TE buffer $(10 \mathrm{mM}$ of Tris $\mathrm{HCl}$, pH 7.4; 1 mM of EDTA, pH 8.0). The DNA was visualized on $1.5 \%$ agarose gel.

FACSCAN ANALYSIS. FACScan analysis of apoptosis was performed according to the procedure of Sard et al. (16). Two million cells per sample were fixed with $2 \%$ paraformaldehyde in PBS, washed twice with TBS (50 mM Tris $\mathrm{HCl}$ in saline solution), and permeabilized for $1 \mathrm{~min}$ with ice cold acetone. Staining was performed by incubating cells for $1 \mathrm{hr}$ at $37^{\circ} \mathrm{C}$ in $25 \mu \mathrm{l}$ of TUNEL reaction mixture-in situ Cell Death Detection Kit (Boehringer, Mannheim, Germany). Samples were analyzed by FACScan (Becton Dickinson, Erembodegem-Aalst, Belgium).

\section{Statistical Analysis}

Descriptive statistics are presented as mean \pm standard deviation. For ordinary data, descriptive statistics are presented with median and percentiles or as percentages. The correlation between p2 1 score and FHIT gene status was calculated from a contingency table. The table was analyzed with Fisher's exact test. Box-Whisker plots were generated in the basic module of the program Statistica. The correlation between apoptosis and FHIT gene status was analyzed with the Wilcoxon rank-sum test. Kaplan-Meier curves were generated for the analysis of time of death (LIFETEST procedure in SAS/Stat). Differences in survival time between groups were compared by the logrank and Wilcoxon tests (also LIFETEST procedure in SAS/Stat). 


\section{Results}

Status of FHIT gene, expression of p2 $1^{\text {waf1 }}$, cell proliferation, and apoptosis were analyzed in head and neck and lung tumor tissues by molecular genetic methods, immunohistochemistry, DNA, and revers transcription PCR (RT-PCR) analysis, $\left[{ }^{3} \mathrm{H}\right]$-thy labeling method, and FACScan analysis in snap-frozen tissues and paraffin-embedded tissue sections.

Expression of the FHIT and p2 $1^{\text {wafl }}$ genes in HNSCCs and in lung carcinomas was analyzed by immunohistochemistry on frozen sections or archival formalin-fixed, paraffin-embedded tissue sections, respectively. Figure 1 shows FHIT protein and p $21^{\text {waf } 1}$ immunostaining of surgically resected HNSCC and lung cancers. The observed staining pattern was essentially similar in all specimens and was represented by the nuclear (p2 $\left.1^{\text {wafl }}\right)$ or cytoplasmic (FHIT protein) staining of tumor cells with the negative surrounding tissue for the both proteins. Of the 120 HNSCC studied, $64(53 \%)$ stained positively for FHIT protein and $20(17 \%)$ stained positively for p2 $1^{\text {wafl }}$. Of the 82 lung cancers studied, $25(30 \%)$ stained positively for FHIT protein and 21 (26\%) stained positively for $\mathrm{p} 2 \mathrm{i}^{\mathrm{wafl}}$. All control sections, which were incubated with nonspecific IgG instead of the primary monoclonal antibody, were also uniformly negative.

\section{Survival Analysis}

In an exploratory, analysis we examined the relationship between outcome of patients suffering from HNSCC monitored in 100-month period and FHIT immunoreactivity results. Survival analysis was performed on 82 patients suffering from lung cancer. The survival curves according to FHIT protein expression are shown in Figure 2A. The median survival time of patients without FHIT expression was 22.46 months and that of the patients with FHIT protein expression 36.04 months. FHIT-negative cases tended to correlate with a worse prognosis; however, this probability did not reach statistical significance. Finally, we analyzed the survival rate of FHIT-positive and FHIT-negative cases of patients classified as having stage III head and neck cancer. Survival analysis was performed on 66 patients monitored over a 130-month period. The median survival time of patients without FHIT protein expression was 30.86 months and that of the patients with FHIT protein expression was 64.04 months. Statistical analysis showed that patients with tumors that were negative for FHIT protein survived significantly longer $(p<0.05)$ (Fig. 2B).

\section{FHIT Gene Status Analysis}

FHIT gene status was examined by RT-PCR analysis for the presence of aberrant FHIT transcripts. Twenty-three HNSCC and 20 lung cancers were examined (Tables 3 and 4). According to the results, tumor samples were divided into two categories: FHIT normal and FHIT aberrant. The results of FHIT gene status by RT-PCR are shown in Figure 3. The size of normal PCR product (normal FHIT gene status) is $814 \mathrm{bp}$, and the sizes of aberrant products are from 350-690 bp. RT-PCR products were directly sequenced after isolation of bands from low melting agarose and purification on columns (QIAGEN, Hilden, Germany). Sequencing of PCR products was performed as described previously (3).

\section{Analysis of Synchronous Head and Neck Lesions}

Table 1 summarizes the results of FHIT gene status, p2 $1^{\text {wafl }}$ expression, and $\left[{ }^{3} \mathrm{H}\right]$-thy labeling in synchronous combinations of normal, precancerous,
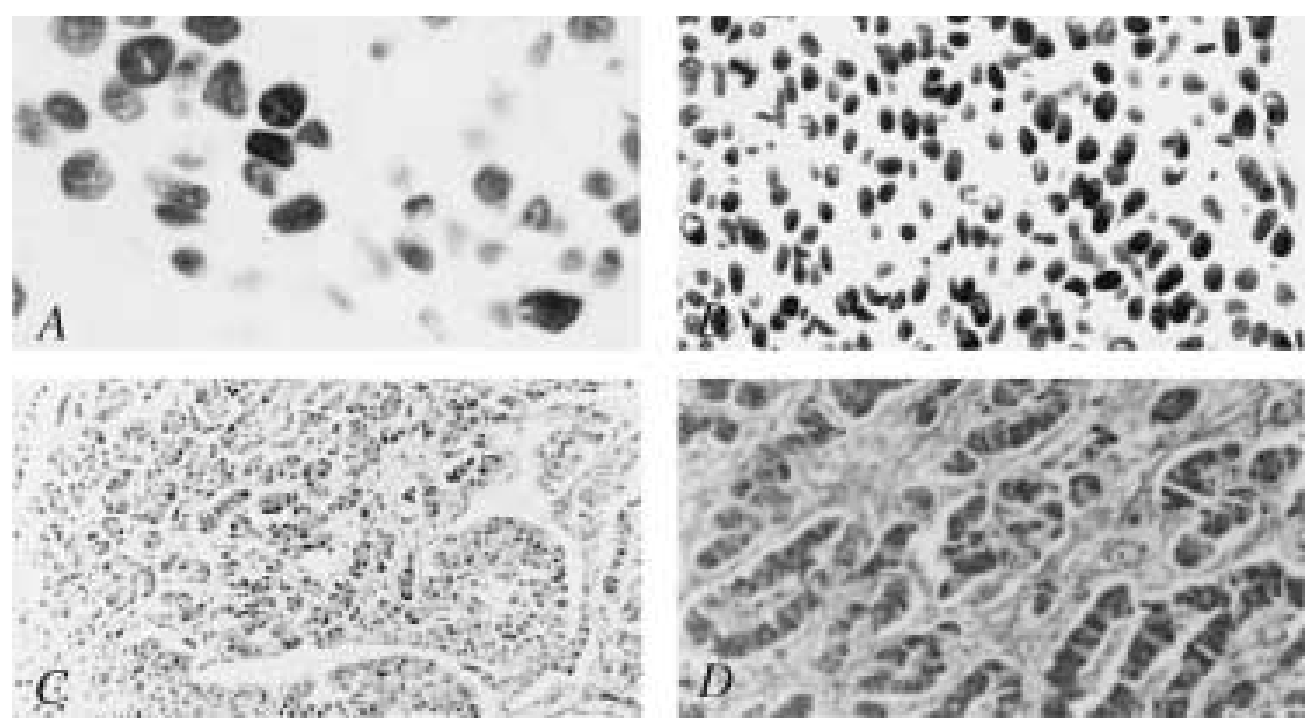

Fig. 1. Immunohistochemical analysis of $221^{\text {waf1 }}$ (A and B) and FHIT (C and D) proteins in HNSCC. 
A

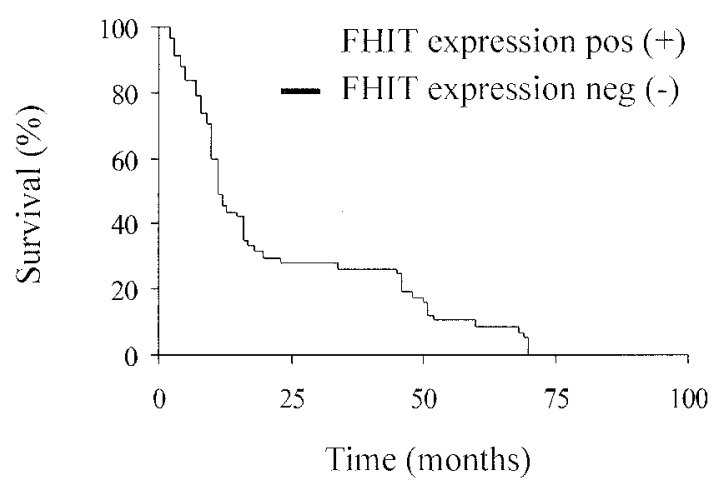

B

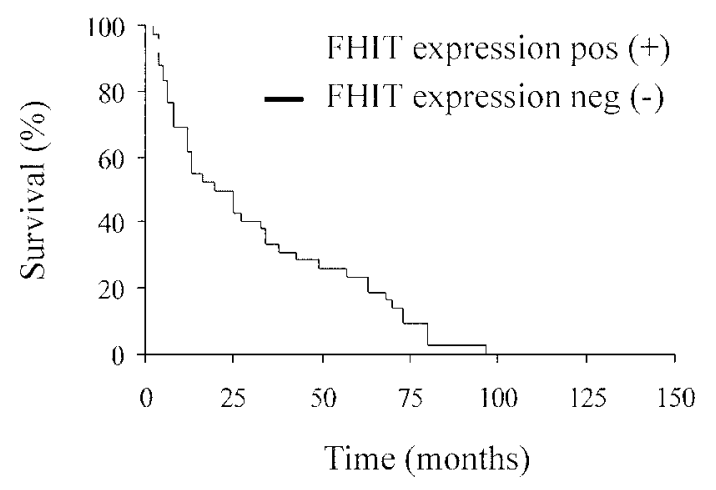

Fig. 2. Kaplan-Meier survival curves after curative resection of FHIT protein positive and FHIT negative carcinomas. (A) Lung cancer. (B) HNSCC.

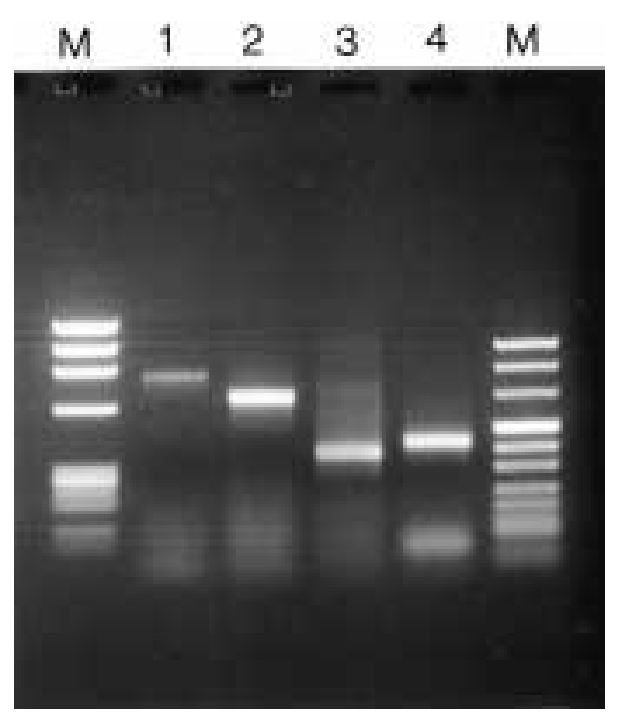

Fig. 3. Expression of the FHIT gene in HNSCC by RTPCR analysis. M, DNA marker; Lane 1, normal transcript 814 bp; Lanes $2-4$, aberrant transcripts. and cancerous head and neck tissues. The majority of the malignant lesions (7 of 12) displayed aberration of FHIT gene, together with low or negative expression of p2 $1^{\text {wafl }}$ and increased intensity of cell proliferation (increased $\left[{ }^{3} \mathrm{H}\right]$-thy incorporation). FHIT gene aberration consisted of missing exons (exon 8, exons 4-8, or exons 5-7) and aberrant (or both aberrant and normal) transcript. In three cases of normal, adjacent-to-lesion tissue contained similar changes in FHIT gene, p2 $1^{\text {wafl }}$ expression (cases 3, 4, and 7) and cell proliferation (cases 4 and 7). Five out of 12 precancerous synchronized lesions contained similar changes in FHIT gene, p2 $1^{\text {wafl }}$ expression, and $\left[{ }^{3} \mathrm{H}\right]$-thy incorporation. Exons 8, 4-8 or 5-7 were missing, and aberrant transcripts of FHIT gene were observed in cases $2,3,4,7$, and 8 together with low or negative expression of $\mathrm{p}^{2} 1^{\text {waf } 1}$ expression, and high intensity of $\left[{ }^{3} \mathrm{H}\right]$-thy labeling.

The observed changes increased with progression of these lesions from normal tissue ( 3 of 12) and dysplasia (5 of 12) to carcinoma in situ (7 of 12) and cancer (9 of 12).

\section{Analysis of Apoptosis}

The results obtained after DNA isolation from disaggregated tumor tissues and electrophoresis on agarose gel are shown in Figure 4. DNAs isolated from two tumor tissues (lanes 3 and 7) are fragmented in small apoptotic fragments. The results obtained by FACScan analysis are shown in Table 4.

\section{Analysis of HNSCC}

Table 4 shows tumor characteristics, patient history, FHIT transcripts, aberrant products and missing

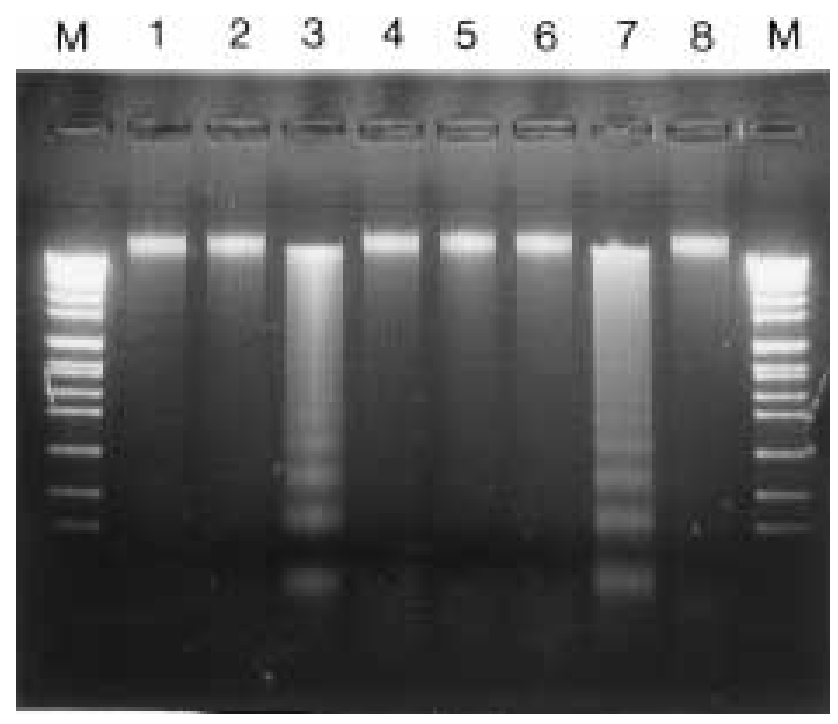

Fig. 4. Agarose gel electrophoresis of small (apoptotic) DNA fragments isolated from lung cancer in $1.5 \%$ agarose. M, DNA molecular weight marker; Lanes 1-8 DNAs isolated from lung cancers; Lanes 3 and 7, apoptosis. 
Table 4. FHIT gene status, smoking and alcohol status, tumor stage, p2l expression, $\left[{ }^{3} \mathrm{H}\right]$-thymidie labeling, and apoptosis in HNSCC.

\begin{tabular}{|c|c|c|c|c|c|c|c|}
\hline Case No. & Tumor Site & S/A Status & Stage & FHIT Status & p21 & {$\left[{ }^{3} \mathbf{H}\right]-$ Thy } & Apoptosis(\%) \\
\hline 1 & Tongue & SA & $\mathrm{T}_{2} \mathrm{~N}_{2 \mathrm{~b}} \mathrm{M}_{\mathrm{X}}$ & At $+\operatorname{Em}(8)$ & 1 & 8.6 & 7 \\
\hline 2 & Tongue & $S$ & $\mathrm{~T}_{2} \mathrm{~N}_{0} \mathrm{M}_{\mathrm{X}}$ & $A t+\operatorname{Em}(8)$ & 2 & 12.5 & 12 \\
\hline 3 & Tongue & $S$ & $\mathrm{~T}_{3} \mathrm{~N}_{2 \mathrm{~b}} \mathrm{M}_{\mathrm{X}}$ & At $+\operatorname{Em}(4-8)$ & 1 & 7.8 & 25 \\
\hline 4 & Tongue & SA & $\mathrm{T}_{2} \mathrm{~N}_{\mathrm{0}} \mathrm{M}_{\mathrm{X}}$ & $\mathrm{N}$ & 3 & 1.5 & 63 \\
\hline 5 & Tongue & SA & $\mathrm{T}_{1} \mathrm{~N}_{0} \mathrm{M}_{\mathrm{X}}$ & $A t+\operatorname{Em}(4-8)$ & 1 & 19.0 & 19 \\
\hline 6 & Tongue & SA & $\mathrm{T}_{1} \mathrm{~N}_{1} \mathrm{M}_{\mathrm{X}}$ & $A t+\operatorname{Em}(5-7)$ & 1 & 7.5 & 30 \\
\hline 7 & Tongue & SA & $\mathrm{T}_{2} \mathrm{~N}_{0} \mathrm{M}_{\mathrm{X}}$ & $\mathbf{N}$ & 3 & 2.0 & 58 \\
\hline 8 & Alveolar ridge & S & $\mathrm{T}_{2} \mathrm{~N}_{\mathrm{0}} \mathrm{M}_{\mathrm{X}}$ & At $+\operatorname{Em}(8)$ & 0 & 12.7 & 14 \\
\hline 9 & Alveolar ridge & S & $\mathrm{T}_{2} \mathrm{~N}_{0} \mathrm{M}_{\mathrm{X}}$ & $A t+\operatorname{Em}(4)$ & 1 & ND & 31 \\
\hline 10 & Alveolar ridge & SA & $\mathrm{T}_{1} \mathrm{~N}_{0} \mathrm{M}_{\mathrm{X}}$ & $A t+\operatorname{Em}(5-8)$ & 2 & 19.5 & 16 \\
\hline 11 & Alveolar ridge & A & $\mathrm{T}_{1} \mathrm{~N}_{1} \mathrm{M}_{\mathrm{X}}$ & $\mathbf{N}$ & 3 & 2.5 & 65 \\
\hline 12 & Alveolar ridge & $\mathrm{s}$ & $\mathrm{T}_{2} \mathrm{~N}_{2} \mathrm{M}_{\mathrm{X}}$ & $\mathrm{N}$ & 1 & 3.5 & 49 \\
\hline 13 & Alveolar ridge & SA & $\mathrm{T}_{2} \mathrm{~N}_{0} \mathrm{M}_{\mathrm{X}}$ & $A t+\operatorname{Em}(4-8)$ & 1 & 7.7 & 17 \\
\hline 14 & Tonsil & - & $\mathrm{T}_{3} \mathrm{~N}_{\mathrm{l}} \mathrm{M}_{\mathrm{X}}$ & $A t+\operatorname{Em}(8)$ & 1 & 18.0 & 23 \\
\hline 15 & Tonsil & A & $\mathrm{T}_{4} \mathrm{~N}_{2 \mathrm{~b}} \mathrm{M}_{\mathrm{X}}$ & $A t+\operatorname{Em}(8)$ & 1 & 9.9 & 29 \\
\hline 16 & Tonsil & SA & $\mathrm{T}_{2} \mathrm{~N}_{1} \mathrm{M}_{\mathrm{X}}$ & $A t+\operatorname{Em}(4-8)$ & 1 & ND & 11 \\
\hline 17 & Tonsil & SA & $\mathrm{T}_{4} \mathrm{~N}_{2 \mathrm{~b}} \mathrm{M}_{\mathrm{X}}$ & $\mathrm{N}$ & 3 & 2.5 & 70 \\
\hline 18 & Tonsil & - & $\mathrm{T}_{2} \mathrm{~N}_{0} \mathrm{M}_{\mathrm{X}}$ & $\mathbf{N}$ & 3 & 1.7 & 59 \\
\hline 19 & Retromolar & SA & $\mathrm{T}_{1} \mathrm{~N}_{0} \mathrm{M}_{\mathrm{X}}$ & $\mathbf{N}$ & 2 & 4.5 & 76 \\
\hline 20 & Retromolar & SA & $\mathrm{T}_{2} \mathrm{~N}_{2 \mathrm{~b}} \mathrm{M}_{\mathrm{X}}$ & $A t+\operatorname{Em}(8)$ & 1 & 2.1 & 18 \\
\hline 21 & Retromolar & s & $\mathrm{T}_{1} \mathrm{~N}_{0} \mathrm{M}_{\mathrm{X}}$ & $A t+\operatorname{Em}(5-7)$ & 1 & 10.9 & 27 \\
\hline 22 & Retromolar & SA & $\mathrm{T}_{2} \mathrm{~N}_{2 \mathrm{~b}} \mathrm{M}_{\mathrm{X}}$ & $A t+\operatorname{Em}(4-8)$ & 1 & ND & 14 \\
\hline 23 & Retromolar & $S$ & $\mathrm{~T}_{2} \mathrm{~N}_{2 \mathrm{~b}} \mathrm{M}_{\mathrm{X}}$ & $A t+\operatorname{Em}(8)$ & 1 & 9.1 & 23 \\
\hline
\end{tabular}

$\mathrm{N}$, normal; ND, not determined; At, aberrant transcript; Em, exon missing (number of exon); $\left[{ }^{3} \mathrm{H}\right]-\mathrm{Thy},\left[{ }^{3} \mathrm{H}\right]-$ thymidie labeling $\left(\times 10^{3}\right)$; S, smoking; A, alcohol.

exons, and expression of $\mathrm{p} 2 \mathrm{1},\left[{ }^{3} \mathrm{H}\right]$-thy incorporation and intensity of apoptosis in HNSCC. Twenty-three HNSCC were analyzed by RT-PCR for the presence of aberrant FHIT transcripts. RNA was isolated, reverse transcribed, and amplified by PCR using primers derived from exons 1 and 10 of the FHIT gene. Aberrant transcripts were observed in 16 of 23 (70\%) tumor samples. Amplified products from most tumors with aberrant transcripts showed both normal and abnormal sized products.

p2 $1^{\text {Waf } 1}$ was over-expressed in five tumors, and moderately expressed in three tumors, mostly in those with normal FHIT gene status. Tumors with aberrant FHIT gene showed very low expression of p2 1 Waf1. These tumors incorporated a higher amount of $\left[{ }^{3} \mathrm{H}\right]$-thy than tumors with normal FHIT gene. Percentage of apoptosis was also in concordance to FHIT gene status. Tumors with aberrant FHIT showed much lower intensity of apoptosis in comparison to tumors with normal FHIT gene.

\section{Analysis of Lung Cancer}

Table 4 shows similar results in lung tumors. Eighteen out of 20 tumors showed aberrant FHIT gene status. Lung carcinomas with aberrant FHIT gene status had generally low expression of $\mathrm{p} 21^{\text {Waf } 1}$, high proliferation activity, and low rate of apoptosis.

\section{FHIT Status and $p 21^{\text {wafl }}$ Expression or Apoptosis}

These results were confirmed in independent experiment with HNSCC. Tumor samples were divided in two categories: FHIT normal (15 tissues) and FHIT aberrant (13 cases). In 7 cases tumor was located in tongue, 13 were located in alveolar ridge, 3 in tonsil, and 5 retromolar. Tumors were in different stages. Figures 5 and 6 show clear differences between FHITaberrant and FHIT-normal tumors. Figure 5 represents frequencies of normal and aberrant FHIT for different expression of p2 1 . Each point on the graph represents one observation. We can see a strong correlation $(p<$ 


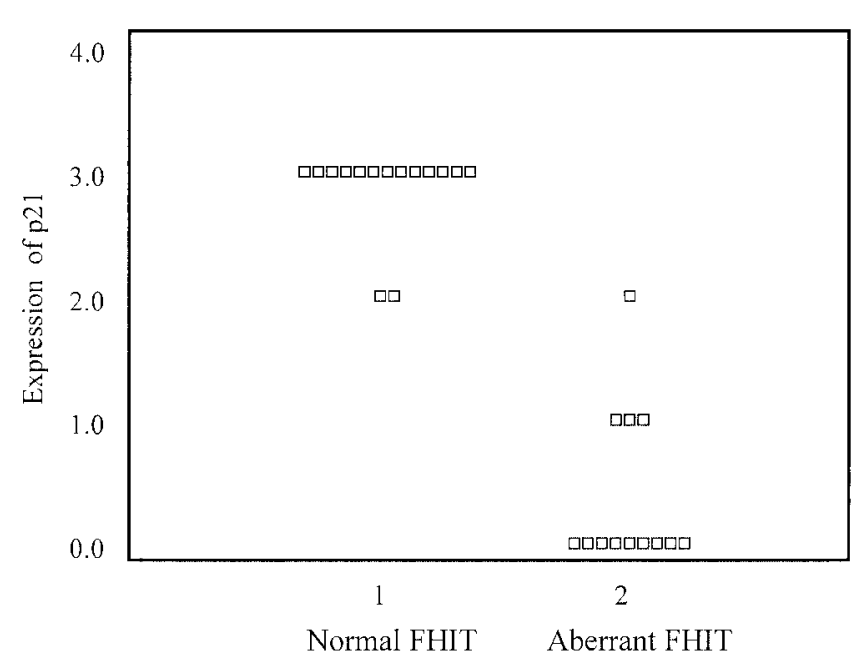

Fig. 5. Correlation between FHIT gene status and $221^{\text {waf } 1}$ protein expression.

$0.01)$ between FHIT gene status and expression of p21. Box-Whisker plot (Fig. 6) showed a statistically significant lower rate of apoptosis in FHIT-aberrant samples in comparison to FHIT-normal tissues $(p<0.01)$.

There was no correlation between FHIT status, p2 $1^{\text {Waf1 }}$, apoptosis, tumor cell proliferation, and tumor stage or location.

\section{LOH Analysis}

To analyze LOH at the FHIT gene, we used two microsatellite markers within the FHIT gene, D3S1300 dinucleotide repeat and D3S4103 trinucleotide repeat. Of the 74 individuals ( 42 with lung cancer and 32 suffering from HNSCC), 51 assayed were informative $(68.9 \%)$ for both markers (Table 3$)$. Normal DNA showed one (homozygous, noninformative patient) or two (heterozygous, informative patient) bands at the both microsatellite markers (Fig. 7). We found high percentage of LOH in both lung tumors and HNSCC (75\% for locus D3S1300 and $79 \%$ for locus D3S4103 in lung cancer and $87 \%$ for D3S1300 and $78 \%$ for lo-

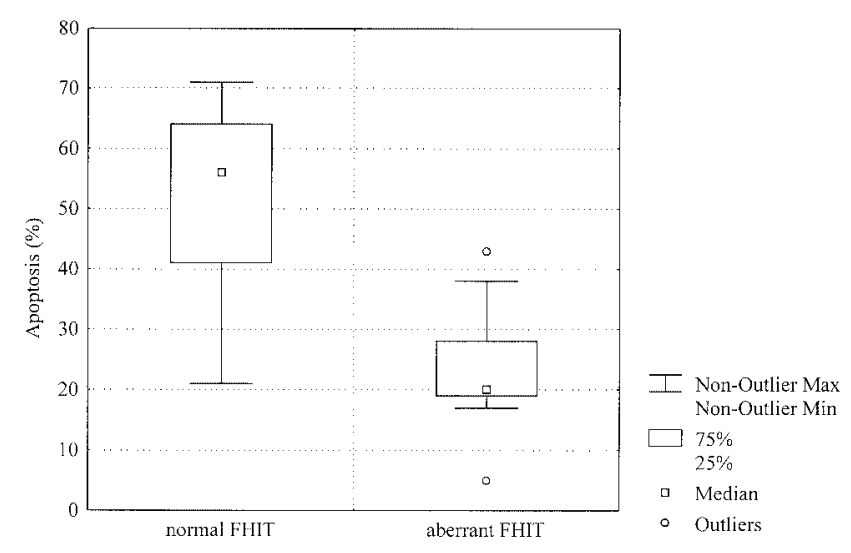

Fig. 6. Correlation between FHIT gene status and apoptosis.

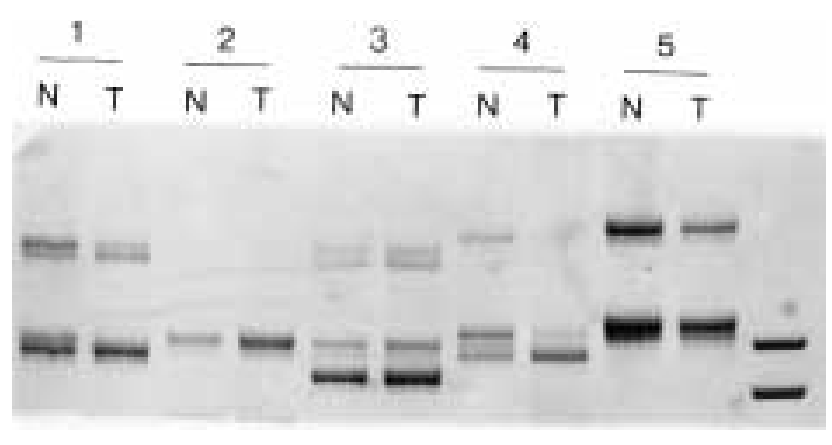

Fig. 7. Loss of heterozygosity (LOH) at microsatellite FHIT gene locus D3S1300 in lung cancer. N, Normal; T, Tumor; 2 and 5 homozygous (not informative); 1 and 4 heterozygous (informative) with LOH; 3 heterozygous without LOH.

cus D3S4103 in HNSCC). Figure 7 presents the examples of microsatellite analysis for D3S1300 marker.

\section{Discussion}

FHIT gene has gained particular consideration as a candidate for tumor suppressor gene because it spans the $t(3 ; 8)$ translocation breakpoint of hereditary renal carcinoma; it spans the FRA3B fragile site, and shows aberrant transcription in some tumor entities and it localizes a region showing frequent alterations in renal carcinomas (5).

FHIT and FRA3B 3pl4.2 allele loss are common in lung cancer and preneoplastic bronchial lesions (26). These findings support the conclusion that FHIT/FRA3B abnormalities are associated with lung cancer pathogenesis but that FHIT abnormalities differ from classic tumor suppressor genes in types of mutations and lack of wild-type transcript. Functional studies are needed to define the role of FHIT gene in thoracic tumorigenesis. Druck et al. (22) examined structure and expression of the human FHIT gene in normal and tumor cells. They concluded that most of the cell lines that exhibited genomic alterations showed alteration of FHIT transcripts and absence or diminution of FHIT protein.

Our results showed that FHIT gene is disrupted in HNSCC and hence, loss of FHIT protein function, together with low expression of p2 $1^{\text {wafl }}$, increased tumor cell proliferation and low rate of apoptosis may be important in the development and/or progression of HNSCC. Virgilio et al. (4) showed multiple genetic alterations of FHIT gene in HNSCC. They analyzed 42 HNSCC tumors by RT-PCR for the presence of aberrant FHIT transcripts. Aberrant transcripts were observed in $62 \%$ of the tumors. Aberrant products from 37 of the 42 tumors displayed both normal- and abnormal-sized products. Five tumors showed multiple abnormal-sized products. Sequence analysis of the 10 aberrant RT-PCR products showed that absence of exon 4 or 5 to exon 8 was the most common abnormality (6 tumors). Aberrant PCR products showed absence of protein coding re- 
gion. Some tumors exhibited homozygous deletion within the FHIT gene; $55 \%$ showed the presence of multiple cell populations with loses of different portions of FHIT alleles by FISH of FHIT genomic clones to interphase nuclei.

Our results and others findings show those FHIT gene deletions frequently involve exons 5-9, including $\mathrm{LOH}$ within this chromosomal region (3). It is conceivable that these deletions affect other expressed sequences. Lux et al. (27) report on identification of five novel expressed sequence tags within 3 p 14.2 that map proximal to exon 9 of the candidate to tumor suppressor gene FHIT. These sequence tags may be valuable for elucidation of the supposed tumor suppressor gene content in 3p14.2.

Our results clearly indicate a correlation between aberrant FHIT gene, increased cell proliferation (low p2 $1^{\text {wafl }}$ expression), a and low rate of apoptosis. Ji et al. (17) suggest that the FHIT gene, when delivered at high efficiency into HI2 199 lung cancer cells by a recombinant adenoviral vector, functions as a tumor suppressor gene both in vitro and in vivo. Overexpression of the FHIT gene induced cell apoptosis and altered cell-cycle processes. The apoptotic cell population markedly increased, and cells accumulated in S-phase after FHIT transduction. Sard et al. (16) transferred FHIT gene into lung cancer cell line H460 lacking FHIT protein expression. Gene transfer resulted in reversion of tumorigenicity. A significant inhibition of cell growth was observed in transfected cells, and again a high rate of apoptosis induced DNA strand breaks in stable clones. FACScan analysis showed an apoptotic rate of $44-47 \%$ compared with a $15 \%$ level in the control $\mathrm{H} 460$ cells. An increased level of p21 protein paralleled by an up-regulation of $\mathrm{p}^{2} \mathrm{1}^{\text {wafl }}$ transcripts also was found in FHIT-expressing clones compared with the H460 cell line. Our results proved clinical relevance of transfection experiments. Observed growth inhibitory effect of FHIT re-expressing cells could be related to apoptosis and cell-cycle arrest and link the tumor-suppressor activity of FHIT protein to its proapoptotic function.

Our clinical data as well as in vitro data obtained by Sard et al. (16) strongly suggest that alteration of FHIT gene is associated with decreased apoptosis, p2 $1^{\text {wafl }}$ expression, and increased cell proliferation. Re-expression of FHIT gene in $\mathrm{H} 460$ cells revealed a significant $G_{0} / G_{1}$ arrest and a presence of sub- $G_{1}$ peak. Cell-cycle analysis showed $53 \%$ of cells in $G_{0} / G_{1}, 46 \%$ in $S$, and $1 \%$ in $G_{2}+M$ phases. A significant increase in $\mathrm{p}^{2} 1^{\mathrm{waf} 1}$ protein expression was noticed in our study as well as in FHIT-protein expressing clones compared with that of the control cells bearing mutant gene (16). No difference in p53 amounts was observed in the same cells suggesting a p53-independent effect. p2 $1^{\text {wafl }}$ protein is a universal cell-cycle inhibitor that specifically binds cyclin-CDK complex and proliferating cell nuclear antigen, acting as a potent growth inhibitor and effector of cell- cycle checkpoints $(28,29,30)$. Increase in $p 21^{\text {waf } 1}$ protein is directly associated with FHIT transcripts (16). Observed effect on $G_{0} / G_{1}$ cycle arrest in FHIT-re-expressing clones could be mediated by p2 $1^{\text {wafl }}$ induction.

A role of FHIT protein as a proapoptotic factor is in agreement with the structural and biochemical studies indicating that FHIT-Ap3A complex is the active FHIT form involved in cellular signaling and with the recent studies linking the induction of apoptosis in human tumors to a decrease in Ap3 A level $(31,32)$.

Our results obtained on synchronous lesions showed clearly that abnormal transcripts of the FHIT gene sometimes could be found in non-neoplastic or premalignant tissues, although observed changes increased with progression of these lesions from normal tissue and dysplasia to carcinoma in situ and cancer. Tanimoto et al. (33) examined abnormalities of FHIT gene in tissue samples of HNSCC along with several leukoplakias and an erythroplakia. Aberrant transcripts could be found in two of seven premalignant lesions; interestingly, in the case of one patient with a premalignant lesion showing an abnormal FHIT transcript, subsequent oral squamous cell carcinoma developed during a 3-year follow-up period. On the other hand, in the two patients from whom both leukoplakia and squamous cell carcinoma samples were taken simultaneously, abnormal FHIT transcripts were found only in squamous cell carcinoma (33).

Our results with synchronous lesions showed that FHIT could be aberrant in normal, adjacent-totumor tissue of head and neck. Occurrence of abnormal transcripts of the FHIT gene has been reported in various types of cancer (6). Tokuchi very recently found that the frequencies of abnormal transcripts were $59 \%$ in lung cancer, $35 \%$ in paired normal lung, and $64 \%$ in normal control lung. The difference between lung cancer and paired normal lung was significant, whereas that between lung cancer and normal control lung was not. Authors concluded that the presence of abnormal FHIT transcripts, in terms of their frequency and variety, is not cancer-specific in lung carcinogenesis, and the abnormality may be mainly due to abnormal splicing and processing of the transcripts (6).

We found LOH in patient with HNSCC and lung cancers. Allele loss involving chromosome arm $3 p$ is one of the most frequent and earliest known genetic events in lung cancer pathogenesis and may affect several potential tumor gene regions. In a recently published study Wistuba et al. (34) showed that $91 \%$ of small cell lung carcinomas and $95 \%$ squamous cell carcinomas demonstrated larger $3 p$ segments of allele loss, whereas $70 \%$ of adenocarcinomas and preneoplastic/preinvasive lesions had smaller areas of $3 p$ allele loss regions with increasing severity of histopathologic preneoplastic/preinvasive changes. Allele loss on $3 p$ is nearly universal in lung 
cancer pathogenesis and involves multiple, discrete, $3 p$ LOH sites that often show a "discontinuous $\mathrm{LOH}^{\prime}$ pattern in individual tumors; it occurs in preneoplastic/preinvasive lesions in smokers with and without lung cancer.

Wistube et al. (34) also found that multiple lesions often lose the same parental allele. LOH frequently involves breakpoints in at least three very small, defined genomic regions. Allele loss and break points first occur in the $600-\mathrm{kb} 3 \mathrm{p} 21.3$ region.

Our results indicate a high incidence of smoking and alcohol consumption in HNSCC and high incidence of smoking history in lung cancer associated with FHIT aberration, a high rate of proliferation, and a low rate of apoptosis. Some other data support such observations. Cigarette smoking could induce molecular alterations of FHIT and p53 gene. Sozzi et al. (14) undertook a molecular study of FHIT and $F R A 3 B$ microsatellite alterations in lung tumors from heavy smokers and in tumors developed in neversmokers to seek genetic damage attributable to tobacco smoking. Their findings suggest that FHIT is a candidate molecular target of carcinogens contained in tobacco smoke. Tobacco smoke contains a mixture of highly mutagenic compounds such as polycyclic aromatic hydrocarbons: in particular benzo $(\alpha)$ piren diol-epoxide $[\mathrm{B}(\alpha) \mathrm{P}]$, which is a major constituent of tobacco smoke. In vitro evidence for $\mathrm{B}(\alpha) \mathrm{P}$ induced formation of DNA adducts of the major mutational hot spots of the p53 gene in human lung cancer has recently been provided (35).

Taken together, our results show a clear correlation between aberrant FHIT gene and a low rate of apoptosis and high rate of tumor cell proliferation. Aberrant FHIT gene could be a prognostic marker in lung cancer, although there is a tendency toward longer survival in HNSCC patients. It can be speculated that the FHIT gene is involved in progression of both lung cancers and HNSCC.

\section{References}

1. Sozzi G, Veronese ML, Negrini M, et al. (1996) The FHIT gene at 3p14.2 is abnormal in lung cancer. Cell 85: 17-26.

2. Kastury K, Baffa R, Druck T, et al. (1996) Potential gastrointestinal tumor suppressor locus at the $3 p 14.2$ FRA3B site identified by homozygous deletions in tumor cell lines. Cancer Res. 56: $978-983$.

3. Ohta M, Inoue H, Cotticelli MG, et al. (1996) The human FHIT gene, spanning the chromosome 3 p 14.2 fragile site acid renal carcinoma-associated $\mathrm{T}(3-8)$ breakpoint, is abnormal in digestive tract cancers. Cell 84: 587-597.

4. Virgilio L, Shuster M, Gollin SM, et al. (1996) FHIT gene alterations in head and neck squamous cell carcinomas. Proc. Natl. Acad. Sci. U.S.A. 93: 9770-9775.

5. Lubinski J, Hadaczek P, Podolski J, et al. (1994) Common regions of deletion in chromosome regions $3 p_{12}$ and $3 p_{14.2}$ in primary clear cell renal carcinomas. Cancer Res. 54: 3710-3713.

6. Tokuchi Y, Kobayashi Y, Hayashi S, et al. (1999) Abnormal FHIT transcripts found in both lung cancer and normal lung tissue. Genes Chromosomes Cancer 24: 105-111.

7. Barnes LD, Garrison PN, Siprashvili Z, et al. (1996) FHIT, a putative tumor suppressor in humans, is a dinucleoside $5^{\prime}, 5^{\prime \prime \prime}-\mathrm{P}^{1}, \mathrm{P}^{3}$-triphosphate hydrolase. Biochemistry 35: 1152911535.

8. Wang N, Perkins KL. (1984) Involvement of band 3p14 in $t(3 ; 8)$ hereditary renal carcinoma. Cancer Genet. Cytogenet. 11: 479-481.

9. Croce CM, Sozzi G, Huebner K. (1999) Role of FHIT in human cancer. J. Clin. Oncol. 17: 1618-1624.

10. Ahsee KW, Cooke TG, Pickford IR, Soutar D, Balmain A. (1994) An allelotype of squamous carcinoma of the head and neck using microsatellite markers. Cancer Res. 54: 1617-1621.

11. Ishwad CS, Ferrell RI, Rossie KM, et al. (1996) Loss of heterozygosity of the short arm of chromosomes 3 and 9 in oral cancer. Int. J. Cancer 69: 1-4.

12. Mao L, Lee JS, Fan YH, et al. (1996) Frequent microsatellite alterations of chromosomes $9 \mathrm{p} 21$ and $3 \mathrm{p} 14$ in oral premalignant lesions and their value in cancer risk assessment. Nat Med 2: 682-685.

13. Wu CL, Sloan P, Read AP, Harris R, Thakker N. (1994) Deletion mapping on the short arm of chromosome 3 in squamous cell carcinoma of the oral cavity. Cancer Res. 54: 6484-6488.

14. Sozzi G, Sard L, De Gregorio L, et al. (1997) Association between cigarette smoking and FHIT gene alterations in lung cancer. Cancer Res. 57: 2121-2123.

15. Siprashvili Z, Sozzi G, Barnes LD, et al. (1997) Replacement of FHIT in cancer cells suppresses tumorigenecity. Proc. Natl. Acad. Sci. U.S.A. 94: 13771-13776.

16. Sard L, Accornero P, Tornielli S, et al. (1996) The tumorsuppressor gene FHIT is involved in the regulation of apoptosis and in cell cycle control. Proc. Natl. Acad. Sci. U.S.A. 96: 8489-8492.

17. Ji L, Fang BL, Yen N, Fong K, Minna JD, Roth JA. (1999) Induction of apoptosis and inhibition of tumorigenicity and tumor growth by adenovirus vector-mediated fragile histidine triad (FHIT) gene overexpression. Cancer Res. 59: 3333-3339.

18. Fong LYY, Fidanza V, Zanesi N, et al. (2000) Muir-Torre-like syndrome in FHIT-deficient mice. Proc. Natl. Acad. Sci. U.S.A. 97: $4742-4747$.

19. Spaventi R, Pečur L, Pavelić K, Pavelić ZP, Spaventi Š, Stambrook PJ. (1994) Human tumor bank in Croatia: a possible model for a small bank as a part of the future European tumor bank network. Eur. J. Cancer 30A: 419-419.

20. Pavelić K, Pavelić ZP, Denton D, Reising J, Khalily M, Preisler HD. (1990) Immunohistochemical detection of C-MYC oncoprotein in paraffin embedded tissue. J. Exp. Pathol. 5: 143-153.

21. Baffa R, Veronese ML, Santoro R, et al. (1998) Loss of FHIT expression in gastric carcinoma. Cancer Res. 58: 4708-4714.

22. Druck T, Hadaczek P, Fu TB, et al. (1997) Structure and expression of the human FHIT gene in normal and tumor cells. Cancer Res. 57: 504-512.

23. Gall-Trošelj K, Kušić B, Pećina-Šlaus N, Pavelić K, Pavelić J. (1995) Nested polymerase chain reaction for detection of hepatitis C virus RNA in blood derivatives. Eur. J. Clin. Chem. Clin. Biochem. 33: 733-736.

24. Pavelić K, Kapitanović S, Radošević S, et al. (2000) Increased activity of $n m 23-H 1$ gene in squamous cell carcinoma of the head and neck is associated with advanced disease and poor prognosis. J. Mol. Med. 78: 111-118.

25. Herrmann M, Lorenz HM, Voll R, Grunke M, Woith W, Kalden JR. (1994) A rapid and simple method for the isolation of apoptotic DNA fragments. Nucleic Acids Res. 22: 5506-5507.

26. Fong KM, Biesterveld EJ, Virmani A, et al. (1997) FHIT and $F R A 3 B 3$ p 14.2 allele loss are common in lung cancer and preneoplastic bronchial lesions and are associated with cancerrelated FHIT cDNA splicing aberrations. Cancer Res. 57: 2256-2267.

27. Lux A, Bardenhener W, Michael D, et al. (1997) Identification of novel expressed sequence tags within the FHIT gene locus in human chromosome region 3p14.2. Hum. Genet. 100: 90-95.

28. Eldeiry WS, Tokino T, Velculescu VE, et al. (1993) WAF1, a potential mediator of p53 tumor suppression. Cell 75: 817-825.

29. Harper JW, Adami GR, Wei N, Keyomarski K, Elledge SJ. (1993) The p2 1 CDK-interacting protein CIP1 is a potent inhibitor of Gl cyclin-dependent kinases. Cell 75: 805-816. 
30. Xiong Y, Hannon GJ, Zhang H, Casso D, Kobayashi R, Beach D. (1993) p21 is a universal inhibitor of cyclin kinases. Nature 366: 701-704.

31. Pace HC, Carrison PN, Robinson AK, et al. (1998) Genetic, biochemical, and crystallographic characterization of FHITsubstrate complexes as the active signaling form of FHIT. Proc. Natl. Acad. Sci. U.S.A. 95: 5484-5489.

32. Kisselev LL, Justesen J, Wolfson AD, Frolova LY. (1998) Diadenosine oligophosphates (AP(N)A), a novel class of signaling molecules. FEBS Lett. 427: 157-163.

33. Tanimoto K, Hayashi S, Tsuchiya E, et al. (2000) Abnormalities of the FHIT gene in human oral carcinogenesis. Br. J. Cancer 82: 838-843.
34. Wistuba II, Behrens C, Virmani AK, et al. (2000) High resolution chromosome $3 p$ allelotyping of human lung cancer and preneoplastic/preinvasive bronchial epithelium reveals multiple, discontinuous sites of $3 p$ allele loss and three regions of frequent breakpoints. Cancer Res. 60: 1949-1960.

35. Denissenko MF, Pao A, Tang M, Pfeifer GP. (1996) Preferential formation of benzo $[\alpha]$ pyrene adducts at lung cancer mutational hotspots in p53. Science 274: 430-432. 